IDENTIFIKASI KOMUNIKASI

ANTARA KELUARGA DENGAN

Jurnal Keperawatan dan

PASIEN PRESBIAKUSIS YANG TINGGAL DALAM SATU RUMAH

Pemikiran IImiah

Amal, A.I (2017). Identifikasi Komunikasi Antara Keluarga Dengan Pasien Presbiakusis Yang Tinggal Dalam Satu Rumah. Nurscope. Jurnal Keperawatan dan Pemikiran IImiah. 3

(6). 43-53

\author{
Ahmad Ikhlasul Amal ${ }^{1}$ \\ Dosen Fakultas IImu Keperawatan Universitas Islam Sultan Agung
}

\title{
ABSTRAK
}

Presbiakusis merupakan kasus yang umum terjadi pada kategori usia lanjut. Pasien presbiakusis dapat merasa diabaikan oleh keluarga dan lingkungan sekitarnya. Komunikasi antara keluarga dengan pasien presbiakusis perlu menggunakan pendekatan yang khusus, agar komunikasi yang dilakukan dapat berjalan secara efektif. Penelitian ini bertujuan untuk mengidentifikasi fenomena komunikasi keluarga dengan pasien presbiakusis yang tinggal dalam satu rumah. Desain penelitian ini adalah kualitatif dengan pendekatan dari sudut fenomenologi. Tehnik pengambilan data dengan cara in-depth interview dan observasi yang dilakukan pada keluarga yang hidup bersama pasien presbiakusis. Dari hasil penelitian didapatkan bahwa pemahaman komunikasi menurut keluarga yaitu berbicara sendiri dan berbicara dengan orang lain. Hambatan keluarga saat berkomunikasi dengan pasien yang mengalami presbiakusis yaitu sulit mengerti apa yang dibicarakan keluarga, susah diajak bicara, tidak nyambung, keluarga merasa jengkel dan harus sabar saat berkomunikasi. Keluarga berkomunikasi dengan pasien presbiakusis dengan menggunakan komunikasi verbal (lisan) seperti mengulang-ulang perkataan, komunikasi non-verbal (isyarat) yaitu dengan gerakan mulut, menyentuh pundak, hadap-hadapan saat berkomunikasi, gerakan tangan. Kesimpulan yang didapatkan diantaranya pemahaman komunikasi, hambatan keluarga saat berkomunikasi dengan pasien presbiakusis, cara keluarga berkomunikasi, alasan keluarga menggunakan komunikasi verbal (lisan) dan non-verbal (isyarat).

Kata kunci: komunikasi keluarga, presbiakusis, fenomena

\section{IDENTIFICATION OF COMMUNICATION BETWEEN FAMILY AND \\ PRESBYACUSIS PATIENT WHO STAYS IN ONE HOUSE}

\begin{abstract}
Presbyacusis hearing loss is common in elderly. Patients with presbyacusis may feel neglected by the family and the surrounding environment. It should be takes the right way to communicate with presbyacusis patients, so that communication can be done effectively. This study aims to identify the phenomenon of family communication with presbyacusis patients who stays in one house. Qualitiataive research design was used in this reserch with phenomenologycal approach. In-depth interviews and observation was used as data collection method. The results of the research found that the family have an understanding about the meaning of communication which is talking alone and talking with others. Family barriers when communicating with presbyacusis patients are difficult to understand what is the family talking about, difficult to talk, disconnected, family feel annoyed and must be patient when communicating. The family communicates with presbyacusis patients using verbal (verbal) communication such as repetition of speech, non-verbal communication (gesture) that is by mouth movement, touching the shoulders, face-to-face when communicating, hand movements. As a conclusion of this research was obtained the understanding of communication, family barriers when communicating with presbiakusis patients, the way families communicate, family reasons using verbal communication (verbal) and non-verbal (cues).
\end{abstract}

Keywords: family communication, presbyacusis, phenomena

Corresponding Author:

Ahmad Ikhlasul Amal ${ }^{1}$, Fakultas Ilmu Keperawatan Universitas Islam Sultan Agung Semarang; e-mail ahmad.ikhlasul@unissula.ac.id

\section{PENDAHULUAN}

Presbiakusis merupakan salah satu gangguan kesehatan yang berisiko terjadi pada usia lanjut. Hal ini disebabkan oleh proses penuaan atau degenerasi pada usia lanjut. Presbiakusis merupakan gangguan 
sensoris yang terjadi pada telinga dan ditandai dengan penurunan kualitas dan kuantitas suara yang diterima pemilik telinga. Penyebab dari presbiakusis itu sendiri adalah perubahan pada telinga luar dan telinga tengah yang berkurang elastisitasnya serta bertambah besar ukuran daun telinga, bertambah kakunya daun telinga, penumpukan serumen, membran timpani yang bertambah tebal dan kaku, juga kekakuan pada persendian tulang pendengaran (Ali, 2006).

Gangguan pendengaran jenis ini banyak dialami oleh usia lanjut. Dalam berkomunikasi dengan pasien presbiakusis membutuhkan pendekatan khusus. Komunikasi adalah proses yang melibatkan seseorang untuk menggunakan tanda-tanda (alamiah atau universal) berupa simbol-simbol (berdasarkan perjanjian manusia) verbal atau non-verbal yang disadari atau tidak disadari yang bertujuan memengaruhi sikap orang lain. Komunikasi yang efektif adalah mencocokkan arti, mencapai konsistensi, dan mencapai kesesuaian antara pesan yang diterima dan diharapkan. Namun pada orang yang mengalami gangguan pendengaran, khususnya pada lansia komunikasi yang efektif dengan menggunakan komunikasi verbal cenderung sulit untuk dicapai maka komunikasi nonverbal yang berperan agar pesan atau ide yang disampaikan komunikator dapat dimengerti oleh lansia, khususnya dalam berkomunikasi dengan keluarga tempat lansia tinggal. Karena keluarga merupakan suatu sistem tempat individu atau anggota keluarga berinteraksi di dalam keluarga (Liliweri, 2009).

Keluarga merupakan support system utama bagi pasien presbiakusis dalam mempertahankan kesehatannya. Peranan keluarga dalam perawatan pasien presbiakusis antara lain merawat, mempertahankan dan meningkatkan status mental, mengantisipasi perubahan sosial ekonomi, serta memberikan motivasi dan memfasilitasi kebutuhan spiritual bagi pasien presbiakusis (Maryam, et.al, 2008). Perilaku dan sikap anggota keluarga dibentuk oleh hubungannya dengan anggota keluarga yang lain. Setiap perubahan pada salah satu anggota keluarga akan mempengaruhi anggota keluarga yang lain. Untuk mengetahui sejauh mana kemampuan keluarga dalam merawat pasien presbiakusis, perlu dikaji pengetahuan keluarga tentang yang dialaminya, bagaimana sikap keluarga terhadap bantuan kesehatan serta bagaimana tindakan keluarga dalam mengatasi kesehatan pasien tersebut (Suprajitno, 2004).

Hasil penelitian yang dilakukan oleh Ismanto (2008) menunjukan bahwa cara berkomunikasi pada lansia mempunyai pengaruh yang dapat membuat lansia merasa diabaikan oleh keluarga maupun lingkungan. Keluarga masih sulit untuk memberikan pemahaman pada lansia yang mengalami

presbiakusis, keluarga berkomunikasi dengan menggunakan komunikasi non-verbal diantaranya bicara dengan diulang-ulang, dan berbicara dengan suara lantang atau keras. Berdasarkan observasi langsung di kelurahan Kalicari RW. 003 Semarang, terdapat dua keluarga yang mempunyai gangguan presbiakusis dimana keluarga mengutarakan keluhannya saat berkomunikasi dengan anggota keluarganya yang mengalami presbiakusis tersebut akibat sering terjadi salah pengertian.

\section{METODE}

Penelitian ini menggunakan desain kualitatif dengan pendekatan fenomenologi. Peneliti mencoba untuk memahami seluruh respon manusia terhadap suatu atau sejumlah situasi. Peneliti dari sudut fenomenologis berusaha memahami arti peristiwa dan kaitannya terhadap orang yang biasa dalam situasi-situasi tertentu. Pada penelitian ini peneliti berusaha memahami mengenai fenomena yang dialami keluarga dalam berkomunikasi dengan pasien yang mengalami presbiakusis disebuah 
komunitas di Kelurahan Kalicari RW.003 Semarang. Data yang dipakai diupayakan berasal dari pendeskripsian objek penelitian terhadap fenomena tentang komunikasi keluarga dengan pasien yang mengalami presbiakusis baik dalam ungkapan, bahasa, tindakan, cara berfikir, dan cara pandang keluarga terhadap masalah tersebut. Partisipan pada penelitian ini adalah keluarga yang mempunyai pasien presbiakusis dan tinggal serumah dengan jumlah partisipan tersaturasi dua keluarga. Alat pengumpulan data yang dipergunakan pada penelitian ini yaitu berupa tape recorder (yang dapat merekam), pita kaset, kamera, buku catatan interview, alat tulis, format wawancara mendalam (pedoman wawancara mendalam), dan pedoman observasi.

\section{HASIL}

A. Hasil Analisa Data Wawancara Mendalam ( in-depth interview )

Tabel 1 kata kunci dan kategori pernyataan partisipan

\begin{tabular}{|c|c|c|}
\hline No & Kata Kunci & Kategori \\
\hline 1. & $\begin{array}{l}\text { a. Bicara sendiri } \\
\text { b. Mengajak orang lain bicara }\end{array}$ & Pemahaman komunikasi \\
\hline 2. & $\begin{array}{l}\text { a. Pasien susah diajak bicara } \\
\text { b. Pasien sulit mengerti } \\
\text { c. Pasien tidak nyambung } \\
\text { d. Keluarga merasa jengkel } \\
\text { e. Harus sabar saat } \\
\text { berkomunikasi }\end{array}$ & Hambatan dalam berkomunikasi \\
\hline 3. & $\begin{array}{ll}\text { a. } & \text { Mengulang-ulang } \\
& \text { perkataan } \\
\text { b. } & \text { Teriak-teriak } \\
\text { c. Gerakan mulut } & \\
\text { d. Menyentuh pundak } \\
\text { e. Hadap-hadapan saat } \\
\text { berkomunikasi dengan } \\
\text { lansia } \\
\text { f. Gerakan tangan }\end{array}$ & $\begin{array}{l}\text { Cara keluarga berkomunikasi } \\
\text { dengan komunikasi verbal (lisan) } \\
\text { dan non-verbal (isyarat) }\end{array}$ \\
\hline 4. & $\begin{array}{ll}\text { a. } & \text { Mempermudah } \\
\text { berkomunikasi } \\
\text { b. Mudah mengerti yang } \\
\text { dimaksud }\end{array}$ & $\begin{array}{l}\text { Alasan keluarga menggunakan } \\
\text { komunikasi non-verbal (Isyarat) }\end{array}$ \\
\hline
\end{tabular}

1. Pemahaman komunikasi.

Data yang diperoleh yaitu berasal dari hasil wawancara kepada P1 dan P2 tentang pemahaman keluarga terhadap komunikasi. Dari penjelasan kedua partisipan (P1 dan P2) pemahaman mereka tentang komunikasi, pada dasarnya kedua partisipan (P1 dan P2) mempunyai jawaban yang sama tentang apa yang dimaksud dengan komunikasi, mereka menganggap bahwa komunikasi adalah tanya jawab, berbicara dengan orang lain, berikut penuturan : 
.... "Yaaa .... setahu saya kalau komunikasi itu ya bicara mas." (Kategori-1

Partisipan 1)

.... "Yaaa.....bicara sendiri juga komunikasi mas yang penting bicara dah mas yang

dinamakan komunikasi, $o_{,}$, ya mas bicara sama orang lain seperti tetangga,

keluarga itu juga komunikasi." (Kategori-1 Partisipan 1)

.... "Yooo mas komunikasi."(Kategori-1 Partisipan 1)

.... "komunikasi itu setahu saya yaa,,, bicara mas. Ya kayak awake dewe (seperti

kita). Kalau ngomong gitulah, tapi saya nggak tahu bahasa sekarang." (Kategori-1

Partisipan 2)

.... "Yaaaa....seperti bicara sama orang lain atau ngajak orang lain bicara mas

yang dimaksud komunikasi." (Kategori-1 Partisipan 2)

Berdasarkan pernyataan partisipan I dan partisipan II terhadap pemahamannya tentang komunikasi, pada partisipan I dan partisipan II mengerti dengan istilah komunikasi. Fenomena yang terungkap dari partisipan I dan partisipan II tentang pemahaman partisipan dalam mengartikan komunikasi sebenarnya hampir sama bahwa komunikasi merupakan suatu bentuk bicara sendiri dan berbicara dengan orang lain atau mengajak orang lain berbicara. Dalam hal ini berbicara sendiri yang dimaksud partisipan adalah suatu bentuk pembicaraan atau penyampaian ide antara diri sendiri dan orang satu dengan orang lain yang didalamnya mempunyai tujuan yaitu untuk membuat orang lain (lawan bicara) mengerti makna apa yang terkandung dalam ide ataupun pesan tersebut. Dalam penelitian ini yang dimaksud lawan bicara dalam berkomunikasi adalah lansia yang mengalami gangguan pendengaran. Dalam hal ini integritas diri memainkan peranan penting, integritas adalah fondasi utama untuk membangun komunikasi yang efektif. Integritas diri menggambarkan kesesuaian antara kelakuan dengan apa yang dikatakan dan di dalamnya terkandung pula unsur saling percaya.

Hal tersebut sesuai dengan pendapat (Potter \& Perry, 2005) bahwa komunikasi adalah elemen dasar dari interaksi manusia yang memungkinkan seseorang untuk menetapkan, mempertahankan dan meningkatkan kontak dengan orang lain. Pada penelitian ini komunikasi yang dilakukan keluarga pada lansia yang mengalami gangguan pendengaran adalah untuk memudahkan dalam memberikan pengertian atas pesan atau keterangan yang disampaikan oleh keluarga. Pernyataan diatas didukung oleh pendapat Akbar (2008), bahwa komunikasi efektif terjadi bila antara komunikator (penyampai pesan) dan komunikan (penerima pesan) saling memahami makna yang terkandung dalam kata yang digunakan. Akan terjadi salah pengertian bila tidak ada kesepahaman makna. Untuk membangun sebuah komunikasi efektif, berikut beberapa hal yang sebaiknya jadi pertimbangan untuk dikembangkan karena sebuah komunikasi yang efektif membutuhkan kontak mata, ekspresi wajah, postur tubuh, dan penampilan fisik secara eksternal. Sedangkan menurut Liliweri (2009), komunikasi yang efektif adalah mencocokkan arti, mencapai konsistensi, dan mencapai kesesuaian antara pesan yang diterima dan diharapkan. Namun pada orang yang mengalami gangguan pendengaran, khususnya pada lansia komunikasi yang efektif dengan menggunakan komunikasi verbal cenderung sulit untuk dicapai maka komunikasi nonverbal yang berperan agar pesan atau ide yang disampaikan komunikator dapat dimengerti oleh lansia, khususnya dalam berkomunikasi dengan keluarga 
tempat lansia tinggal. Karena keluarga merupakan suatu sistem tempat individu atau anggota keluarga berinteraksi di dalam keluarga.

2. Hambatan dalam berkomunikasi.

Keterangan yang diperoleh dari masing-masing partisipan (P1 dan P2) merasa kesulitan saat berkomunikasi dengan pasien presbiakusis untuk menyampaikan suatu pesan ataupun pernyataan, sehingga sering terjadi salah pengertian pada lansia tersebut. Adapun kesulitan yang dirasakan baik P1 maupun P2 adalah :

.... "Yaaa...biasane mbahe itu kalau diajak bicara nggak ngerti, jadi ya kadangkadang saya mengulang-ulang kalau mengajak bicara, kalau diajak bicara nggak nyambung gitu Ihoo mas."(Kategori-3 Partisipan-1)

.... "Gini Iho mas kalau saya bilang kiri mbahe jawab kanan Ihah seperti itu mas yang saya maksud ngak nyambung."(Kategori-3 Partisipan-1)

.... "Masalahnya ya...susah ya mas komunikasi dengan ibu itu, kan ibu memang tidak dapat mendengar, kadang saya tanya ibu malah nggak jawab apa-apa mas ibu cuman meneng waei (diam saja) dan sukar diberi pengertian."(Kategori-3 Partisipan-2)

.... "Gini Iho mas ... ibu itu susah bangat kalau lagi dikasi tau ma saya jika saya berutahukan sesuatu susah bangat mas."(Kategori-3 Partisipan-2)

.... "Gieh mas harus sabar."(Kategori-3 Partisipan-2)

Berdasarkan pernyataan partisipan I dan partisipan II tentang masalah yang dihadapi saat berkomunikasi dengan pasien dengan presbiakusis, yaitu pernyataan kedua partisipan pada intinya sama tentang masalah atau kesulitan yang timbul saat berkomunikasi dengan pasien presbiakusis diantaranya sulit mengerti, susah diajak bicara, dan perkataan tidak sesuai dengan apa yang dibicarakan. Hal tersebut dibuktikan dengan pernyataan partisipan bahwa jika berbicara dengan pasien presbiakusis cenderung mengalami kesulitan karena sulit memahami apa yang disampaikan oleh keluarga (partisipan), terkadang jika partisipan baik partisipan I maupun partisipan II mengajak pasien berbicara sesuatu, misal ditanya A pasien menjawab B sehingga pembicaraan tersebut terkesan tidak sesuai.

Menurut Potter dan Perry (2005), masalah adalah respon aktual atau potensial klien terhadap kesehatan atau penyakit. Dari pernyataan partisipan tentang masalah yang timbul saat berkomunikasi dengan pasien presbiakusis yaitu terletak pada sejauh mana pemahaman (pengetahuan) pasien tentang pesan atau hal apa yang sedang dibicarakan oleh keluarga (partisipan), karena pemahaman seseorang tentang pesan yang diterima sangat menentukan apakah komunikasi itu berhasil atau tidak.

Pernyataan tersebut sesuai dengan pendapat Notoatmodjo (2010) yang menyebutkan bahwa pemahaman diartikan sebagai kemampuan menjelaskan secara benar tentang objek yang diketahui dan dapat menginterpretasikan materi tersebut secara benar. Orang yang telah paham terhadap objek atau materi harus dapat menjelaskan, menyebutkan contoh, dan menyimpulkan terhadap objek yang dipelajari. 
Perlu diketahui keluarga bahwa untuk berkomunikasi dengan pasien presbiakusis agar pesan yang disampaikan mudah dipahami, maka keluarga harus bisa menempatkan cara yang tepat seperti; menggunakan bahasa yang mudah dipahami, berbicara secara pelan, menghindari berbicara atau menyampaikan pesan yang terlalu banyak atau panjang hal ini dilakukan karena pesan yang terlalu banyak akan membingungkan lansia yang mengalami gangguan pendengaran. Pendapat diatas juga sesuai dengan Potter dan Perry (2005), yang menyatakan bahwa pada pasien presbiakusis penggunaan kata-kata yang lebih sedikit, dapat mengarahkkan kepada kebingungan yang lebih sedikit. Kejelasan akan dapat dicapai dengan berbicara secara perlahan dan dengan pengucapan yang jelas.

3. Cara keluarga mengatasi masalah komunikasi.

Data yang diperoleh saat wawancara yang dilakukan pada kedua partisipan pada intinya mereka mengalami kesulitan saat berkomunikasi dengan pasien presbiakusis, khususnya komunikasi yang dilakukan secara verbal. Karena lansia sering mengalami salah pengertian akibat dari gangguan pendengaran yang dialaminya. Jadi keluarga menggunakan bahasa non-verbal saat berkomunikasi dengan pasien tersebut. Pernyataan diatas dapat diungkapkan baik P1 maupun P2 yaitu :

.... "Ya sering mas kalau jengkel, memang ya orang tua kalau diajak bicara sudah tidak nyambung, kadang saya itu ya teriak-teriak kalau mbahe tidak ngerti-ngerti diajak bicara."(Kategori-4 Partisipan-1)

...."Yaaa...ngak mas, mbahe nggak ngerasa lagi dimarahi atau saya lagi teriakteriak, mbahe ngerasa kalau saya lagi bicara seperti biasa, ya mbahe diam aja mas."(Kategori-4 Partisipan-1)

...."Ya kalau mbahe itu susah diajak bicara, ya pokoknya ya saya ulang-ulang perkataan kalau ingin mbahe cepat ngerti. Kalau mbahe diajak bicara itu harus menghadap ke mbahe biar mbahe ngerti kalau diajak bicara atau harus disentuh, yaa saya pegang pundaknya. Kadang-kadang kalau saya ingin memberi makan gitu ya kadang-kadang tangan saya ini saya gerakkan, arahkan ke mulut biar mbahe ngerti kalau akan diajak makan."(Kategori-4 Partisipan-1)

...."Caranya ya umpama kita mau bicara sama ibu, kita hanya dengan menjawil (menyentuh) bahunya biar ibu mengerti kalau diajak bicara sama saya atau keluarga yang lain. Pokoknya ya selalu dengan isyarat, menjawil (menyentuh), ya begitulah mas....soalnya ibu kan tidak dapat mendengar dengan jelas."(Kategori4 Partisipan-2)

...."Ya isyarat seperti tadi menggerakan mulut diumik-umik sambil menggerakan tangan untuk mempermudah ibu mengerti saat diajak bicara sama saya atau menjawil (menyentuh)bahu ibu, itu juga yang sering dilakukan sama keluarga yang lain saat bicara sama ibu mas."(Kategori-4 Partisipan-2) 
Berdasarkan pernyataan partisipan I dan partisipan II tentang cara keluarga mengatasi kesulitan berkomunikasi dengan pasien presbiakusis yaitu berfokus pada sikap seperti menyentuh lansia, bicara dengan sabar dan teriak-teriak, bicara dengan diulang-ulang, menggunakan isyarat (gerakan tubuh) dan menghadap ke orang yang mengajak bicara. Partisipan mengungkapkan hal itu karena diyakini dengan cara tersebut akan dapat memudahkan partisipan dalam berkomunikasi dengan pasien presbiakusis. Hal ini dilakukan karena biasanya pada usia lanjut memang sulit untuk cepat menangkap apa yang disampaikan oleh keluarganya. Berikut ini pernyataan yang mendukung dari kedua partisipan yang pernyataan tersebut hampir sama, bahwa kalau kita bicara dengan pasien presbiakusis itu tidak usah keras-keras yang penting lansia mengerti gerakan mulut dari yang mengajak bicara ini tadi atau dengan memberi isyarat seperti menyentuhnya jika akan mengajak pasien tersebut berbicara dengan harapan pasien tersebut memfokuskan perhatiannya. Karena pada pasien tersebut sangat sulit untuk memahami pembicaraan orang lain yang tertuju padanya yang berbeda dengan orang normal, apalagi jika pembicaraan dengan lansia tersebut tidak dibantu dengan gerakan anggota badan seperti menggunakan tangan ataupun gerakan bibir atau yang disebut dengan komunikasi non-verbal.

Dimana komunikasi non-verbal menurut Potter dan Perry (2005), adalah transmisi pesan tanpa menggunakan kata-kata, dan merupakan salah satu cara yang terkuat bagi seseorang untuk mengirimkan pesan kepada orang lain, karena gerakan tubuh memberi makna yang lebih jelas daripada kata-kata. Sedangkan komunikasi verbal atau lisan adalah proses penyampaian pesan yang disampaikan melalui kata-kata yang diucapkan maupun yang ditulis (Potter dan Perry, 2005). Pernyataan diatas didukung oleh pendapat Tamsuri (2005), bahwa kemampuan komunikasi pada lansia (lanjut usia) dapat mengalami penurunan akibat penurunan fungsi berbagai sistem organ, seperti penglihatan, pendengaran, wicara dan persepsi. Semua ini menyebabkan penurunan kemampuan lansia menangkap pesan atau informasi dan melakukan transfer informasi. Gangguan pendengaran menyebabkan lansia hanya dapat mendengar suara yang relatif keras dan pada tempo suara yang lebih lambat. Kadang kala gangguan pendengaran terlalu parah sedemikian sehingga orang tua memerlukan alat bantu dengar dan perlu melihat mimik (gerak bibir) untuk kemudian menyimpulkan apa yang telah diucapkan orang lain. Karena menurut Ali (2006), gangguan pendengaran pada lanjut usia adalah gangguan sensoris yang terjadi pada telinga yang ditandai dengan penurunan kualitas dan kuantitas suara yang diterima pemilik telinga.

Perlu diingat bahwa dalam berkomunikasi dengan pasien presbiakusis tidak semudah dengan jika kita berkomunikasi dengan orang yang pendengarannya normal, maka dalam hal ini dibutuhkan suatu cara yang setidaknya dapat membantu untuk mempermudah keluarga maupun orang lain dalam berkomunikasi dengan pasien tersebut. Karena pada penelitian ini anggota keluarga partisipan I dan partisipan II adalah orang yang paling dekat dengan pasien, dan yang membantu untuk memenuhi kebutuhan pasien sehari-hari, dimana partisipan I adalah menantu dari anak pertama sedangkan partisipan II adalah anak kandung ke-3, masing-masing pasien tersebut tinggal dengan partisipan berserta suami dan anak-anaknya. Sehingga segala aktivitas dan kebutuhan pasien tersebut harus dibantu oleh partisipan, dan partisipan I juga menyebutkan bahwa untuk merawat lansia dengan gangguan pendengaran seperti memenuhi kebutuhannya (misal; memberi makan, menyiapkan kebutuhan lainnya) membutuhkan kesabaran dan harus mengerti keadaan pasien, karena sikap kita yang tidak bersahabat (seperti tidak memperhatikan jika diajak lansia berbicara) bisa membuat pasien tersinggung dan merasa diabaikan, dan hal serupa juga dialami oleh partisipan II. 
Pernyataan diatas sesuai dengan pendapat Azwar (2002), bahwa sikap adalah suatu bentuk evaluasi atau reaksi perasaan mendukung atau memihak dan perasaan tidak mendukung atau tidak memihak. Jadi sikap dari keluarga disini mempunyai peranan penting dalam menciptakan komunikasi yang efektif pada lansia yang mengalami gangguan pendengaran. Hal diatas sesuai dengan pendapat Potter dan Perry (2005), bahwa sentuhan bersifat lebih spontan dari komunikasi verbal, dan secara umum sentuhan menjadi lebih otentik. Berbagai pesan seperti rasa cinta, dukungan emosi, dorongan, kelembutan dan perhatian personal ditunjukkan dengan sentuhan. Jadi sentuhan disini merupakan salah satu cara yang bisa dipergunakan khususnya bagi keluarga yang merawat agar komunikasi dengan lansia yang mengalami gangguan pendengaran menjadi lebih efektif.

1) Teriak-teriak dan hadap-hadapan dengan pasien saat berkomunikasi

Berdasarkan fenomena komunikasi yang dilakukan keluarga pada pasien presbiakusis. Pada salah satu partisipan mengungkapkan bahwa cara untuk mengatasi kesulitan dalam berkomunikasi dengan pasien, yaitu saling hadap-hadapan dengan pasien. Hal tersebut juga didukung oleh hasil observasi yang dilakukan peneliti, yaitu terlihat bahwa saat partisipan I berbicara partisipan tersebut berusaha untuk bisa berhadapan dengan pasien. Maksud partisipan menggunakan cara ini yaitu untuk memudahkan memberikan pemahaman pada lansia tentang pesan yang disampaikan, dan sekiranya pasien tidak begitu mendengar apa yang disampaikan namun pasien masih bisa mempelajari gerakan bibir dari partisipan tersebut.

Hal tersebut juga sesuai dengan pendapat Tamsuri (2005), bahwa gangguan pendengaran menyebabkan lansia hanya dapat mendengar suara yang relatif keras dan pada tempo suara yang lebih lambat. Kadang kala gangguan pendengaran terlalu parah sedemikian sehingga orang tua memerlukan alat bantu dengar dan perlu melihat mimik (gerak bibir) untuk kemudian menyimpulkan apa yang telah diucapkan orang lain.

2) Berbicara dengan diulang-ulang

Dari pernyataan partisipan ada pernyataan tentang cara untuk mengatasi kesulitan dalam berkomunikasi dengan pasien yaitu berbicara dengan diulang-ulang, dari hasil observasi juga didapatkan gambaran bahwa dalam berbicara dengan lansia partisipan cenderung mengulang kata atau pembicaraan yang telah disampaikan. Hal ini ditujukan agar pasien bisa dengan mudah memahami apa yang disampaikan oleh partisipan sebagaimana yang disampaikan oleh Potter dan Perry (2005), bahwa pengulangan bagian pesan yang penting juga akan membuat komunikasi menjadi lebih jelas. Jadi dengan keluarga menggunakan cara tersebut diatas untuk mengatasi kesulitan dalam berkomunikasi dengan pasien yang mengalami gangguan pendengaran, diharapkan pasien tersebut dapat menikmati masa tuanya dengan perasaan senang, dihargai, dan dibutuhkan meskipun lansia tersebut memiliki kekurangan, sehingga kecemasan pada diri pasien tentang keadaannya tidak lagi terjadi.

4. Alasan keluarga menggunakan komunikasi verbal dan non-verbal.

Saat dilakukan wawancara yang dilakukan kedua partisipan pada intinya kedua keluarga mendapatkan kemudahan saat berkomunikasi dengan cara masing-masing partisipan hampir sama pada pernyataan yang telah diungkapkan baik P1 dan P2 adalah: 
...."Ya biar mbahe itu cepat ngerti, soalnya ya orang sudah tua ya seperti itu mas. Harus tekun, sabar kalau merawat orang seperti mbahe mas."(Kategori-5 Partisipan-1)

...."Ya cuman cara itu aja yang saya sering lakukan ma mbahe mas."(Kategori-5 Partisipan-1)

...."Karena ya....biar saya mudah berkomunikasi sama ibu, paling nggak ibu itu ngerti kalau diajak ngomong, ngerti apa yang saya maksud. Lhaa wong pernah saya bicara agak keras katanya nyentak (bentak), kan repot mas jadinya. Lha kalau mau ngerumet (merawat), mau ngasi makan umpamanya ya saya sodorkan, kemudian dengan isyarat lag. Dan harus selalu sabar karena memang yaaa dengan orang tua harus selalu sabar, seperti anak kecil lagilah pokoknya."(Kategori-5 Partisipan-2)

Saat dilakukan wawancara kepada kedua partisipan pada intinya kedua keluarga mendapatkan kemudahan saat berkomunikasi dengan cara masing-masing partisipan hampir sama pada pernyataan yang telah diungkapkan baik partisipan I dan partisipan II seperti pasien memahami atau mengerti apa yang diucapkan oleh keluarga, dan dapat mengikuti instruksi yang diperintahkan oleh keluarga. Dimana dibenarkan bahwa komunikasi non-verbal menurut Potter dan Perry (2005), adalah transmisi pesan tanpa menggunakan kata-kata, dan merupakan salah satu cara yang terkuat bagi seseorang untuk mengirimkan pesan kepada orang lain, karena gerakan tubuh memberi makna yang lebih jelas daripada kata-kata. Sedangkan komunikasi verbal atau lisan adalah proses penyampaian pesan yang disampaikan melalui kata-kata yang diucapkan maupun yang ditulis (Potter dan Perry, 2005).

\section{PEMBAHASAN}

\section{Partisipan I}

Partisipan memahami bahwa pasien presbiakusis mengalami gangguan pendengaran namun jika keluarga timbul rasa jengkel partisipan membentak pasien, sehingga pasien menjauh dan membuang muka. Partisipan dapat mengendalikan diri saat berkomunikasi dengan pasien, partisipan tidak sampai membanting sesuatu yang membahayakan kesehatan terutama fisik pasien. Partisipan mendengarkan pasien saat berkomunikasi bila suasana hati keluarga baik, tetapi apabila partisipan merasa lelah dan bosan partisipan mengabaikan atau tidak mendengarkan apa yang disampaikan pasien, artinya tidak ada hubungan timbal balik saat partisipan berkomunikasi dengan pasien. Partisipan mengatakan saat berkomunikasi menggunakan kata-kata sopan, lemah lembut, namun disisi lain peneliti melihat bahwa apa yang disampaikan partisipan tidak sesuai yang dilakukan berbeda, tetangga juga membenarkan hal tersebut bahwa partisipan dan pasien komunikasinya buruk (tidak sopan dan membentak). Pasien memahami bahasa yang digunakan keluarga saat berkomunikasi karena partisipan menggunakan bahasa tubuh (isyarat) seperti saat diajak berkomunikasi, keluarga menyentuh pundak lansia, dan menggerakan tangan sambil menyentuh bibir saat diajak makan (P1). 


\section{Partisipan II}

Ada hubungan timbal balik saat pasien berkomunikasi dengan partisipan karena pasien merespon apa yang diperintahkan dan diberitahukan patisipan. Partisipan berkomunikasi dengan pasien menggunakan kata-kata yang baik, sopan dan tidak berkata kotor. Partisipan dan pasien saling menghargai saat berkomunikasi, ini dapat dilihat dari cara partisipan menyampaikan informasi pada pasien. Partisipan lebih bersabar dalam mengadapi pasien, karena partisipan mengerti dan memahami keadaan pasien terutama saat berkomunikasi sehari-hari. Partisipan menggunakan bahasa isyarat dalam berkomunikasi dengan pasien seperti menyentuh pundak pasien dan sambil bibir diumik-umik. Partisipan kadang jika merasa lelah dan bosan mendengarkan pasien berkomunikasi atau pasien meminta sesuatu kadang patisipan mengabaikan pasien. Partisipan dapat mengendalikan dan mengontrol emosi saat berkomunikasi dengan pasien, partisipan lebih memilih berkomunikasi dengan menggunakan non-verbal saat komunikasi berlangsung (P2).

\section{SIMPULAN}

Pemahaman komunikasi menurut keluarga yaitu berbicara sendiri dan berbicara dengan orang lain. Hambatan keluarga saat berkomunikasi dengan lansia yang mengalami gangguan pendengaran yaitu pasien dengan presbiakusis sulit mengerti apa yang dibicarakan keluarga, susah diajak bicara, tidak nyambung atau tidak sesuai jika diajak bicara, keluarga merasa jengkel dan harus sabar saat berkomunikasi. Cara keluarga berkomunikasi dengan pasien presbiakusis dengan menggunakan komunikasi verbal (lisan) seperti mengulang-ulang perkataan dan sedangkan komunikasi non-verbal (isyarat) yaitu dengan gerakan mulut, menyentuh pundak, hadap-hadapan saat berkomunikasi, gerakan tangan. Alasan keluarga menggunakan komunikasi verbal (lisan) dan non-verbal (isyarat) tersebut untuk mempermudahkan komunikasi keluarga dengan pasien presbiakusis.

\section{SARAN}

Keluarga hendaknya lebih banyak memberikan waktu, dan perhatian serta kasih sayang yang lebih kepada lansia yang mengalami gangguan pendengaran dalam meningkatkan harga diri lansia dan agar pasien tidak merasa diabaikan. Selain itu juga perawat juga memiliki peran untuk meyakinkan pasien presbiakusis untuk tetap berkomunikasi dengan orang lain yang ada disekitarnya.

Hasil penelitian ini perlu lebih dikembangkan dengan area penelitian yang lebih luas dan subjek penelitian yang lebih banyak. Penelitian menggunakan desain kuantitaif perlu dicoba untuk mendapatkan informasi lainnya.

\section{DAFTAR PUSTAKA}

Ali, I. (2006). Mengatasi gangguan pada telinga dengan tanaman obat. Cetakan pertama. Jakarta: Agro Media Pustaka.

Depkes RI. (2002). Pedoman Pembinaan Kesehatan Lanjut Usia Bagi Petugas Kesehatan; Jilid II Materi Pembinaan. Jakarta: Direktorat Jenderal Bina Kesehatan Masyarakat. http://www.perpustakaan.depkes.go.id/cgi-bin/koha/opac-detail.pl?bib=3482. Diunduh tanggal 06 Desember 2012.

Liliweri, A. (2009). Dasar - dasar Komunikasi Kesehatan. Cetakan III. Pustaka Pelajar, Yogyakarta. 
Maryam, R. S., et,al. (2008). Mengenal Usia Lanjut dan Perawatannya. Jakarta: Salemba Medika.

Notoatmodjo, S. (2010). Metodologi Penelitian Kesehatan. Jakarta: Rineka Cipta.

Pawito. (2007). Penelitian Komunikasi Kualitatif. Yogyakarta: PT. LKIS Pelangi Angkasa.

Poter, P. A., \& Perry, A. G. (2005). Buku Ajar Fundamental Keperawatan; konsep, proses, dan praktek, alih bahasa: Yasmin Asih. Jakarta: EGC.

Prijosaksono, A. (2007). Komunikasi Efiktif Dalam Tim. Retrieved February 19, 2008, from http://www.sinarharapan.co.id.

Suara Merdeka. (2009). Mei 30, 2009, google scholar, from http://www.search-results.com.

Suprajitno. (2004). Rencana Asuhan Keperawatan Keluarga; Aplikasi dalam Praktek. Jakarta: EGC.

Syatriani. (2008). Hubungan Kemampan Komunikasi Dengan Kemandirian Pada Remaja Tunarungu. $\begin{array}{llll}\mathrm{Di} & \mathrm{SMPLB} & \text { Bagian } & \text { B. From }\end{array}$ http://www.gunadarma.ac.id/library/articles/graduate/psychology/Artikel10502209.pdf

Tamsuri, A. (2005). Komunikasi Dalam Keperawatan. Jakarta: EGC

Wawan, A. \& Dewi. M. (2010). Pengukuran Pengetahuan Sikap Dan Perilaku Manusia. Yogyakarta: Nuha Media. 